\title{
NADPH oxidase signal transduces angiotensin II in hepatic stellate cells and is critical in hepatic fibrosis
}

\author{
Ramón Bataller, ${ }^{1}$ Robert F. Schwabe, ${ }^{1}$ Youkyung H. Choi, ${ }^{2}$ Liu Yang, ${ }^{1}$ Yong Han Paik, ${ }^{1}$ \\ Jeffrey Lindquist, ${ }^{1}$ Ting Qian, ${ }^{3}$ Robert Schoonhoven, ${ }^{1}$ Curt H. Hagedorn, ${ }^{2}$ \\ John J. Lemasters, ${ }^{3}$ and David A. Brenner ${ }^{1}$ \\ ${ }^{1}$ Department of Medicine and Department of Biochemistry and Biophysics, University of North Carolina at Chapel Hill, \\ Chapel Hill, North Carolina, USA \\ ${ }^{2}$ Department of Medicine, Emory University School of Medicine, Atlanta, Georgia, USA \\ ${ }^{3}$ Department of Cell and Developmental Biology, University of North Carolina at Chapel Hill, Chapel Hill, North Carolina, USA
}

\begin{abstract}
Angiotensin II (Ang II) is a pro-oxidant and fibrogenic cytokine. We investigated the role of NADPH oxidase in Ang II-induced effects in hepatic stellate cells (HSCs), a fibrogenic cell type. Human HSCs express mRNAs of key components of nonphagocytic NADPH oxidase. Ang II phosphorylated $\mathrm{p} 47^{\mathrm{phox}}$, a regulatory subunit of NADPH oxidase, and induced reactive oxygen species formation via NADPH oxidase activity. Ang II phosphorylated AKT and MAPKs and increased AP-1 DNA binding in a redox-sensitive manner. Ang II stimulated DNA synthesis, cell migration, procollagen $\alpha 1(\mathrm{I})$ mRNA expression, and secretion of TGF- $\beta 1$ and inflammatory cytokines. These effects were attenuated by $N$-acetylcysteine and diphenylene iodonium, an NADPH oxidase inhibitor. Moreover, Ang II induced upregulation of genes potentially involved in hepatic wound-healing response in a redoxsensitive manner, as assessed by microarray analysis. HSCs isolated from $\mathrm{p} 47 \mathrm{phox}-/-$ mice displayed a blunted response to Ang II compared with WT cells. We also assessed the role of NADPH oxidase in experimental liver fibrosis. After bile duct ligation, $\mathrm{p} 4 \mathrm{p}_{\mathrm{phox}-/-}$ mice showed attenuated liver injury and fibrosis compared with WT counterparts. Moreover, expression of smooth muscle $\alpha$-actin and expression of TGF- $\beta 1$ were reduced in $\mathrm{p} 47_{\mathrm{phox}-/-}$ mice. Thus, NADPH oxidase mediates the actions of Ang II on HSCs and plays a critical role in liver fibrogenesis.
\end{abstract}

J. Clin. Invest. 112:1383-1394 (2003). doi:10.1172/JCI200318212.

\section{Introduction}

Liver fibrosis is the common consequence of chronic liver injury of any etiology (1). Advanced liver fibrosis disrupts the normal liver architecture, causing hepatocellular dysfunction and portal hypertension. Unfortunately, no effective hepatic antifibrotic therapies are available. The hepatic stellate cells (HSCs) are a major fibrogenic cell type in the liver (2). Following injury, HSCs are activated to myofibroblast-like cells, which promote collagen deposition. Recent evidence indicates that angiotensin II (Ang II) may be an important media-

Received for publication February 26, 2003, and accepted in revised form August 20, 2003.

Address correspondence to: David A. Brenner, Department of Medicine, Columbia University College of Physicians and Surgeons, 622 West 168th Street, New York, New York 10032, USA. Phone: (212) 305-5838; Fax: (212) 305-9822;

E-mail: dab2106@columbia.edu.

David A. Brenner's present address is: Department of Medicine,

Columbia University College of Physicians and Surgeons,

New York, New York, USA.

Conflict of interest: The authors have declared that no conflict of interest exists.

Nonstandard abbreviations used: hepatic stellate cell (HSC); angiotensin II (Ang II); Ang II type 1 (AT1); reactive oxygen species (ROS); diphenylene iodonium (DPI); $N$-acetylcysteine (NAC); 2',7'-dichlorofluorescein diacetate (DCFDA); 4-hydroxy-

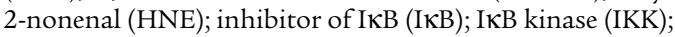

glutathione-S-transferase; monocyte chemoattractant protein-1 (MCP-1). tor in liver fibrosis. Serum Ang II levels are frequently elevated in patients with cirrhosis, and a local reninangiotensin system is upregulated in experimental hepatic fibrogenesis $(3,4)$. Patients with chronic hepatitis $\mathrm{C}$ and a genetic polymorphism associated with increased Ang II synthesis have been reported to develop more severe fibrosis (5). Moreover, inhibition of Ang II synthesis and/or the blockade of Ang II type 1 (AT1) receptors markedly attenuate inflammation and fibrosis in experimental models of chronic liver injury (6-10). However, the cellular and molecular mechanisms underlying the apparent fibrogenic effect of Ang II on the liver are unknown. In other tissues, Ang II is locally synthesized during tissue remodeling and exerts an array of biological actions on resident myofibroblasts (11). In the injured liver, activated HSCs are potential targets for Ang II, since they express functional AT1 receptors (12).

Reactive oxygen species (ROS) play an important role in hepatic fibrosis (13). Increased ROS and resulting oxidative stress are commonly detected in livers from patients with alcohol abuse, hepatitis $\mathrm{C}$ virus infection, iron overload, or chronic cholestasis, as well as in most types of experimental liver fibrogenesis (14-18). Moreover, antioxidant agents attenuate hepatic fibrosis in rodents and may exert beneficial effects in patients with chronic liver diseases $(19,20)$. The cellular origin and molecular mechanisms underlying the fibrogenic effect of ROS are under investigation. CYP2E1-derived 
ROS from damaged hepatocytes can induce phenotypic activation, proliferation, and increased collagen synthesis in cultured HSCs (21-23). An alternative source of ROS in the injured liver is NADPH oxidase. This enzyme generates large amounts of superoxide anions in phagocytic cells and plays a key role in immune defense (24). Recently, a nonphagocytic form of NADPH oxidase has been demonstrated in vascular cell types (25). Like the phagocytic respiratory burst $\mathrm{NADPH}$ oxidase, nonphagocytic NADPH oxidase reduces molecular oxygen to generate superoxide, which is in turn converted to hydrogen peroxide. However, unlike the phagocytic type, the NADPH oxidases present in blood vessels are constitutively active, producing relatively low levels of ROS under basal conditions and generating higher levels of oxidants in response to cytokines such as Ang II. Increased ROS production results in the stimulation of redox-sensitive intracellular pathways $(26,27)$. Both the phagocytic and nonphagocytic oxidases are multimeric enzymes composed of plasma membrane-associated proteins as well as cytosolic factors (28). In the phagocytic NADPH oxidase, the plasma membrane-associated proteins gp91 phox and p22 ${ }^{\text {phox }}$ compose the flavocytochrome b558 complex, which forms the catalytic subunit of the oxidase. Cytosolic factors, which include $\mathrm{p} 47 \mathrm{phox}$, are phosphorylated by agonists and translocate to the cell membrane to form the active NADPH oxidase. In VSMCs, gp91phox is barely expressed, suggesting that other subunits are present to form catalytically active NADPH oxidase. Recently, several smooth muscle cell homologs of gp91 ${ }^{\text {phox }}$, termed Nox (nonphagocytic oxidase), have been identified (29).

In alcohol-induced liver disease, NADPH oxidase appears to be a key oxidant, as mice lacking p47phox a cytoplasmic component required for enzymatic activation, do not develop alcoholic liver disease (30). Moreover, inhibition of NADPH by diphenylene iodonium (DPI) attenuates alcoholic liver disease (31). Kupffer cells highly express phagocytic NADPH oxidase and generate high amounts of ROS during early liver injury (32). However, it is unknown whether other nonparenchymal cells such as HSCs express NADPH oxidase and whether this enzyme regulates the response to fibrogenic cytokines such as Ang II. In this study, we demonstrate that activated HSCs express NADPH oxidase to generate ROS, which mediate the multiple fibrogenic actions of Ang II. Moreover, mice lacking a functional NADPH oxidase are resistant to liver fibrosis. These data indicate that activation of NADPH oxidase plays an important role in the wound-healing response to chronic liver injury.

\section{Methods}

Chemicals. Ang II, $N$-acetylcysteine (NAC), DPI, and PD123319 were purchased from Sigma-Aldrich (St. Louis, Missouri, USA). Losartan was kindly provided by Merck \& Co. (Rahway, New Jersey, USA). 2',7'-Dichlorofluorescein diacetate (DCFDA) was obtained from
Molecular Probes Inc. (Eugene, Oregon, USA). PD98059, SB203580, and LY294002 were purchased from Calbiochem-Novabiochem Corp. (La Jolla, California, USA). SP600125 was obtained from Celgene Corp. (San Diego, California, USA).

Animals and treatments. NADPH oxidase-deficient (p47phox-/-) C57BL/6 mice, which lack a critical cytosolic component required for assembly of an active NADPH oxidase complex, were expanded in parallel with parental inbred WT mice $(30,33)$. Two-monthold female mice were used for HSC isolations and for experimental liver fibrosis. Liver fibrosis was induced by bile duct ligation. Briefly, mice were anesthetized with sodium pentobarbital. After midline laparotomy, the common bile duct was doubly ligated with 4-0 silk and transected between the two ligations. Sham operation was performed similarly except that the bile duct was not ligated and transected. Mice were randomized to undergo bile duct ligation or sham operation. Ten mice were used in each group. All animals were sacrificed 2 weeks after surgery, and blood and liver samples were obtained. Mice were housed in a pathogenfree barrier facility accredited by the Association for the Accreditation and Assessment of Laboratory Animal Care. All procedures were approved by the Investigation and Ethics Committee and Institutional Animal Care and Use Committee of the University of North Carolina at Chapel Hill.

Cell culture. Human HSCs were isolated from surgical specimens of normal human livers as previously described (34). After isolation, cells were seeded on uncoated plastic tissue-culture dishes and cultured in DMEM (GIBCO BRL; Life Technologies Inc., Grand Island, New York, USA) supplemented with 15\% FCS. Experiments were performed in five independent preparations between passages 2 and 5. Rat HSCs were isolated from male Sprague-Dawley rats ( $>400 \mathrm{~g}$ ) as previously described (35). Mouse HSCs were isolated from WT (C57BL/6) and $\mathrm{p} 47 \mathrm{phox}-/-$ mice as previously described (36). Both rat and mouse HSCs were cultured in DMEM supplemented with $10 \%$ FCS. Rat hepatocytes were isolated from male Sprague-Dawley rats $(250 \mathrm{~g})$ as described previously (37). Hepatocytes were plated on dishes coated with rat type I collagen in Waymouth's medium (GIBCO BRL; Life Technologies Inc.) containing $10 \% \mathrm{FCS}, 0.1 \mathrm{mmol} / \mathrm{l}$ insulin, and $0.1 \mathrm{mmol} / 1$ dexamethasone. After 2 hours, the cultures were washed with PBS and changed to RPMI medium (GIBCO BRL) containing $0.1 \mathrm{mmol} / \mathrm{l}$ insulin, $2 \mathrm{mmol} / \mathrm{l}$ L-glutamine, $5 \mathrm{mg} / \mathrm{ml}$ transferrin, $1 \mathrm{nmol} / 1$ selenium, and $1.52 \mu \mathrm{mol} / \mathrm{l} \mathrm{FFAs}$.

Serum biochemical measurements. Serum alanine aminotransferase (ALT), aspartate aminotransferase (AST), and bilirubin levels were measured using standard enzymatic procedures by the Pathology Department of the University of North Carolina at Chapel Hill.

Histochemical studies. Paraffin-embedded sections were stained with H\&E and Masson's trichrome. For immunohistochemical analysis, sections were deparaf- 
finized, rehydrated, and stained using the DAKO EnVision system protocol (DAKO Corp., Carpinteria, California, USA). Sections were incubated with antismooth muscle $\alpha$-actin (1:1,000; DAKO Corp.) and anti-TGF- $\beta 1$ (1:1,000; Santa Cruz Biotechnology Inc., Santa Cruz, California, USA) for 30 minutes at room temperature. As negative controls, all specimens were incubated with an isotype-matched control antibody. The area of positive staining was measured using a Macintosh-based morphometric analysis system (Apple Computer Inc., Brea, California, USA) with MetaMorph software (Universal Imaging Corp., Downingtown, Pennsylvania, USA).

Quantification of hepatic collagen content. Collagen content was assessed both by morphometric analysis of Sirius red staining of liver sections and by hydroxyproline concentration. The area of positive Sirius red staining was measured using MetaMorph software. Hydroxyproline content was quantified colorimetrically from $0.2-\mathrm{g}$ liver samples. Tissue was homogenized in $6 \mathrm{~N} \mathrm{HCl}$ and hydrolyzed at $110^{\circ} \mathrm{C}$ for 16 hours. The hydrolysate was filtered, aliquots were evaporated under vacuum, and the sediment was redissolved in 50\% isopropanol. Samples were then incubated in a solution containing $0.84 \%$ chloramine-T $42 \mathrm{mM}$ sodium acetate, $2.6 \mathrm{mM}$ citric acid, and $39.5 \%$ ( $\mathrm{vol} / \mathrm{vol}$ ) isopropanol ( $\mathrm{pH} 6.0)$ for 10 minutes at room temperature. Next, samples were incubated in a solution containing $0.248 \mathrm{~g} p$-dimethylaminobenzaldehyde dissolved in $0.27 \mathrm{ml}$ of $60 \%$ perchloric acid and $0.73 \mathrm{ml}$ of isopropanol for 90 minutes at $50^{\circ} \mathrm{C}$. Hydroxyproline content was quantified photometrically at $558 \mathrm{~nm}$. The results were expressed as micrograms hydroxyproline per gram liver.

Measurement of intracellular ROS. Cells cultured in 24well plates were loaded with the redox-sensitive dye DCFDA $(10 \mu \mathrm{M})$ for 20 minutes at $37^{\circ} \mathrm{C}$. Cells were then rinsed twice with DMEM and stimulated with agonist. DCFDA fluorescence was detected at excitation and emission wavelengths of $488 \mathrm{~nm}$ and $520 \mathrm{~nm}$, respectively. ROS formation was measured using a multiwell fluorescence scanner (CytoFluor 2300; Millipore Corp., Bedford, Massachusetts, USA) and a Zeiss LSM 510 confocal laser-scanning microscope (Carl Zeiss, Oberkochen, Germany).

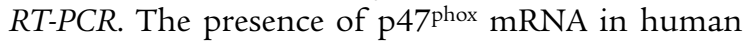
HSCs was investigated by semiquantitative RT-PCR. Total RNA was extracted from cultured cells and normal human livers using TRIzol reagent (Invitrogen Corp., Carlsbad, California, USA). One microgram of RNA was reverse-transcribed using $\mathrm{dT}_{15}$-oligonucleotide and Moloney murine leukemia virus reverse transcriptase (Perkin-Elmer Applied Biosystems, Foster City, California, USA) in $25 \mu \mathrm{l}$ of volume. Specific primers were designed as follows: p47phox: sense 5'-GTACCCAGCCAGCACTATG-3', antisense 5'-GTCTGGTTGTCTGTGGGGAG-3'; gp91 phox: sense $5^{\prime}$-GAATGGGGAAAAATAAAGGAATG-3', antisense 5'-ACCCTTCTTCATCTGTAGC-3'; Nox1: sense 5'-CCAGGATTGAAGTGGATGGT-3', antisense 5'-CGGTGAGGAAGAGACGGTAG-3'. Reactions were per- formed using $1 \mu \mathrm{M}$ primers in a $50-\mu \mathrm{l}$ total volume containing $1.5 \mathrm{mM} \mathrm{MgCl}_{2}, 50 \mathrm{mM} \mathrm{KCl}$, and $10 \mathrm{mM}$ Tris $(\mathrm{pH}$ 8.3). PCR amplification was carried out by 30 cycles of denaturation $\left(96^{\circ} \mathrm{C}, 30\right.$ seconds), annealing $\left(62^{\circ} \mathrm{C}, 45\right.$ seconds), and extension $\left(72^{\circ} \mathrm{C}, 20\right.$ seconds). PCR products were analyzed by electrophoresis in a $1.5 \%$ agarose gel. GAPDH amplification was used to demonstrate equal RNA load.

RNase protection assay. Rat-liver total RNA was obtained using the TRIzol. RNase protection assay for procollagen $\alpha 1(\mathrm{I})$ was performed as previously described (35). Ten micrograms of total RNA was hybridized with $5.10^{5} \mathrm{cpm}$ of riboprobe. Riboprobes were derived from the 375-bp PstI-AvaI fragment from rat procollagen $\alpha 1(\mathrm{I}) \mathrm{cDNA}$, cloned into HincII-PstI sites of the pGEM $3 z f+$ vector, and from the plasmid pTRI-GAPDH-rat (Ambion Inc., Austin, Texas, USA). Twenty micrograms of yeast transfer RNA (tRNA) was hybridized as a negative control. The protected riboprobes were visualized by autoradiography and quantitated by PhosphorImager analysis (Molecular Dynamics, Sunnyvale, California, USA).

Western blotting. Whole-cell extracts were obtained in Triton lysis buffer, and liver extracts were obtained in modified radioimmunoprecipitation buffer as previously described (37). Western blotting was performed under standard conditions. Antibodies against 4-hydroxy-2nonenal (HNE; Alpha Diagnostic International Inc., San Antonio, Texas, USA), phosphoserine (Zymed Laboratories Inc., San Francisco, California, USA), phospho-ERK, phospho-p38 MAPK, phospho-AKT (Cell Signaling Technology Inc., Beverly, Massachusetts, USA), heme oxygenase-1, $\alpha$-tubulin, inhibitor of $\kappa B-\alpha(\mathrm{I} \kappa \mathrm{B} \alpha)$, p47phox, and phospho-Jun (Santa Cruz Biotechnology Inc.) were used at a dilution of 1:1,000. For detection of collagen I secretion, cells were cultured in $100-\mathrm{mm}$ culture dishes $\left(10^{6}\right.$ cells per dish). Cells were stimulated with agonists for 20 hours, and $4 \mathrm{ml}$ of cell media were precipitated with $0.76 \mathrm{~g}$ of sodium sulfite at $4^{\circ} \mathrm{C}$ for 3 hours and then centrifuged at $10,000 \mathrm{~g}$ for 30 minutes. Pellets were resuspended in $0.5 \mathrm{M}$ acetic acid, and $40-\mu \mathrm{l}$ aliquots were subjected to electrophoresis on a $7.5 \%$ acrylamide gel. After blotting, membranes were probed with anti-human collagen type I antibody $(1: 1,000$; BIODESIGN International, Saco, Maine, USA), which recognizes the procollagen $1(\mathrm{I})$ chain, the mature $1(\mathrm{I})$ chain, and the heterotrimer of type I collagen. Prior to electrophoresis, some samples were digested at room temperature for 30 minutes with pepsin (1,000 U; Sigma) at pH 2.5 or with bacterial collagenase (7.5 U; Roche Molecular Biochemicals, Indianapolis, Indiana, USA) as controls for antibody specificity. Treatment with collagenase resulted in complete loss of signal, whereas treatment with pepsin resulted in reduction of the molecular mass from 170 to $120 \mathrm{kDa}$ (not shown).

Kinase assays. Kinase reactions were performed as previously described (38). For IKB kinase (IKK) assay, $300 \mu \mathrm{g}$ proteins were immunoprecipitated with $2 \mu \mathrm{l}$ anti-IKK $\gamma$ (a gift from F. Mercurio, Celgene Corp.) for 2 hours 
followed by $20 \mu \mathrm{l}$ protein A/G-agarose (Santa Cruz Biotechnology Inc.) for 1 hour. Kinase reaction was performed using glutathione-S-transferase-IKB (GST-IкB) as a substrate (a gift from H. Sakurai, Tanabe Seiyaku Co., Osaka, Japan). For the JNK assay, $50 \mu \mathrm{g}$ protein was incubated with $1 \mu \mathrm{l}$ GST-c-Jun bound to GST beads washed, and subjected to a kinase reaction. For the extracellular signal-regulated kinase (ERK) assay, 200 $\mu \mathrm{g}$ proteins were immunoprecipitated with $2 \mu \mathrm{l}$ anti-ERK-2 (Santa Cruz Biotechnology Inc.) for 2 hours followed by $20 \mu \mathrm{l}$ protein $\mathrm{A} / \mathrm{G}$-agarose for 1 hour. The kinase reaction was performed using myelinic basic protein (Sigma) as a substrate. For the p38 MAPK assay, $250 \mu \mathrm{g}$ proteins were immunoprecipitated with $5 \mu \mathrm{l}$ of immobilized anti-p38 antibody (Santa Cruz Biotechnology Inc.), and the kinase reaction was performed using myelinic basic protein as a substrate. For the AKT assay, $250 \mu \mathrm{g}$ protein was immunoprecipitated with 4 $\mu \mathrm{l}$ of immobilized AKT antibody (Santa Cruz Biotechnology Inc.). The kinase reaction was performed using a GSK-3 fusion protein as a substrate.
Electrophoretic mobility shift assay. Cell nuclear proteins were extracted as described previously (39). Eight micrograms of nuclear proteins were incubated with $100 \mathrm{pg}$ of a ${ }^{32} \mathrm{P}$-labeled probe containing the AP- 1 consensus site (5'-GTAAAGCATGAGTCAGACACCTC- $\left.3^{\prime}\right)$ in buffer containing $10 \mathrm{mM}$ HEPES ( $\mathrm{pH} 7.8$ ), $2 \mathrm{mM} \mathrm{MgCl} 2,50$ $\mathrm{mM} \mathrm{KCl}, 1 \mathrm{mM}$ DTT, $0.1 \mathrm{mM}$ EDTA, and 20\% glycerol in the presence of single-stranded oligonucleotide (25 $\mu \mathrm{g} / \mathrm{ml}$ ) and Poly (dI-dC) (Amersham Biosciences Corp., Piscataway, New Jersey, USA) $(25 \mu \mathrm{g} / \mathrm{ml})$ for 20 minutes at room temperature. For competition assay, one sample was incubated with $10 \mathrm{ng}$ unlabeled probe.

Preparation of RNA and cDNA microarrays. Activated human HSCs were cultured in $150-\mathrm{mm}$ dishes until confluent. Cells were serum-starved overnight and then stimulated with buffer or agonists for 24 hours. Total RNA was isolated using TRIzol. Thirty micrograms of RNA from each sample was used to prepare cRNA probes as described in the manufacturer's protocol (Affymetrix Inc., Santa Clara, California, USA). Probes were hybridized to gene chips (Affymetrix Inc. a

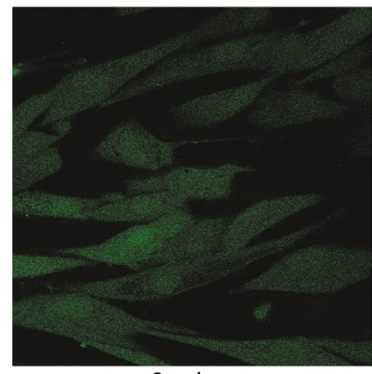

$0 \min$

b

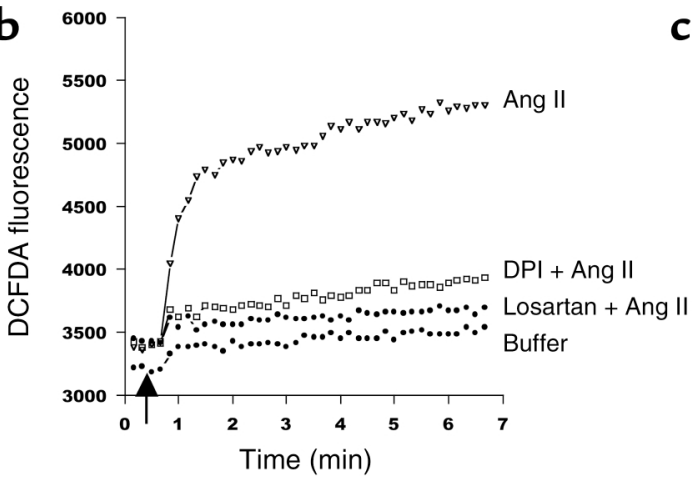

Buffer + Ang II

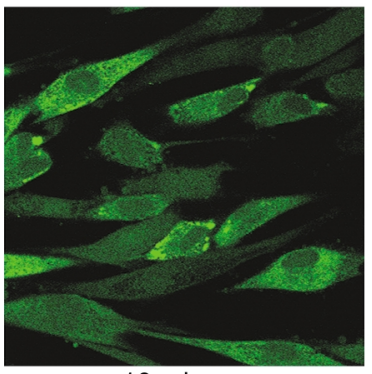

$10 \min$

C

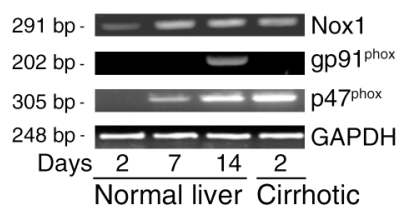

$0 \min$
DPI + Ang II
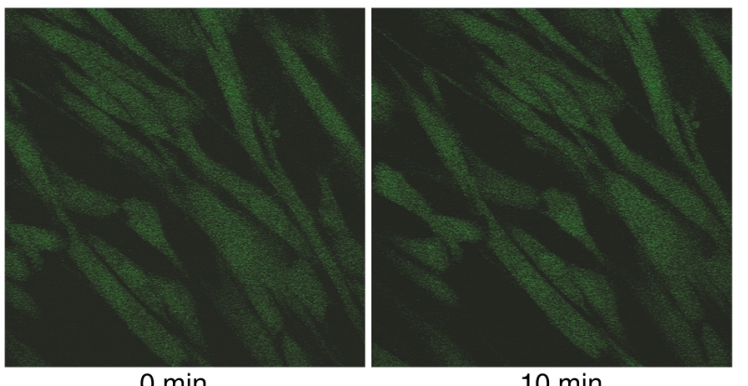

$10 \mathrm{~min}$
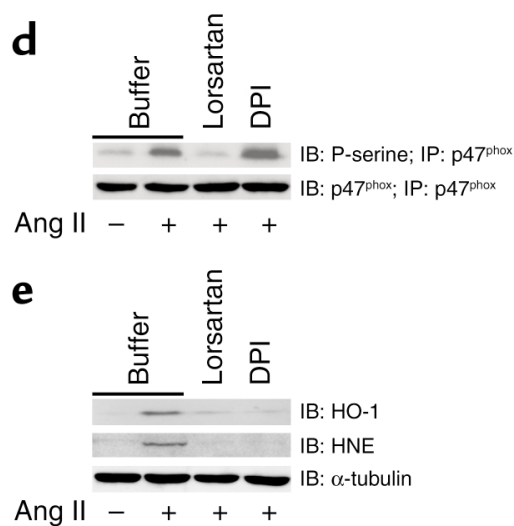

\section{Figure 1}

Ang II increases ROS formation and lipid peroxidation in human HSCs via NADPH activity. (a) HSCs were loaded with DCFDA (10 mM) and studied with laser confocal microscopy. Ang II ( $\left.10^{-8} \mathrm{M}\right)$ markedly increased cell fluorescence. This effect was prevented by DPI (10-6 $\left.\mathrm{M}\right)$. (b) Quantification of fluorescent changes in DCFDA-loaded cells using a fluorometer at excitation and emission wavelengths of $488 \mathrm{~nm}$ and $520 \mathrm{~nm}$, respectively. Ang II increased cell fluorescence that was blocked by DPI and losartan $\left(10^{-7} \mathrm{M}\right)$. Data are representative of three independent experiments. (c) Expression of mRNA encoding p47phox, gp91phox, and Nox1 in human HSCs, as assessed by RT-PCR. Quiescent HSCs ( 2 days in culture after isolation from a normal human liver), human HSCs activated in culture (cells isolated from normal livers and cultured for 14 days), and HSCs activated in vivo (2 days in culture after isolation from a human cirrhotic liver) were studied. GAPDH was amplified to demonstrate equal loading. (d) Ang II phosphorylates p47phox in human HSCs. Cells were treated with Ang II for 5 minutes, and cell extracts were immunoprecipitated with anti-p47phox antibody and blotted with either anti-p47phox antibody or anti-phosphoserine (P-serine) antibody. (e) Ang II induces HNE protein adducts and upregulates heme oxygenase-1 (HO-1) protein expression in HSCs. HSCs were stimulated for 12 hours with Ang II, and cell extracts were blotted with anti-HNE and anti-heme oxygenase- 1 antibodies. Cells were preincubated with buffer, DPI, or losartan before addition of Ang II. $\alpha$-Tubulin was used to demonstrate equal loading. 
a

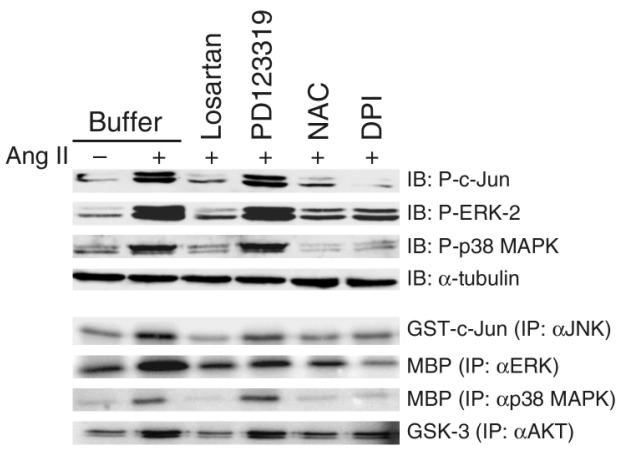

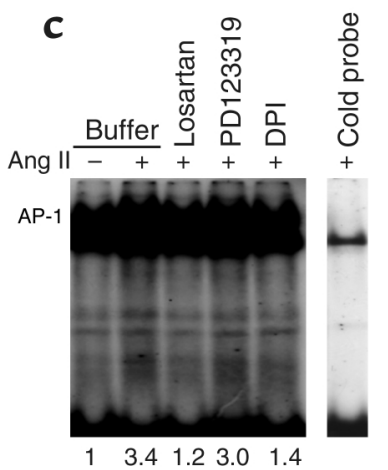

\section{Figure 2}

Ang II stimulates intracellular signaling pathways in human HSCs in a redox-sensitive manner. (a) Ang II stimulates phosphorylation of MAPK proteins and AKT in a redox-sensitive manner. HSCs preincubated with buffer, losartan $\left(10^{-7} \mathrm{M}\right)$, the AT2 receptor antagonist PD123319 $\left(10^{-7} \mathrm{M}\right)$, NAC $\left(10^{-4} \mathrm{M}\right)$, or DPI $\left(10^{-6} \mathrm{M}\right)$ were stimulated for 10 minutes with Ang II $\left(10^{-8} \mathrm{M}\right)$. Twenty-five micrograms of cell extracts were subjected to Western blotting using anti-phospho-ERK-2, anti-phospho-c-Jun, and anti-phospho-p38 MAPK antibodies. Anti- $\alpha$-tubulin antibody was used to demonstrate equal protein loading. ERK-2, JNK, AKT, and p38 MAPK activities were assessed by specific kinase assays (see Methods). Cells were stimulated for 10 minutes with Ang II $\left(10^{-8} \mathrm{M}\right)$ in the presence or absence of losartan, PD123319, NAC, and DPI. (b) Ang II does not induce phosphorylation of STAT1 and STAT3. Cells were stimulated for 10 minutes with Ang II $\left(10^{-8} \mathrm{M}\right)$ or IFN- $\gamma(100 \mathrm{U} / \mathrm{ml})$, and $25 \mu \mathrm{g}$ of cell extracts were subjected to Western blotting using anti-phosphoSTAT1 and -STAT3 antibodies. Anti- $\alpha$-tubulin antibody was used to demonstrate equal protein loading. (c) Ang II activates AP-1 DNA binding in human HSCs. Stimulation with Ang II $\left(10^{-8} \mathrm{M}\right)$ for 2 hours increased AP-1 binding, as assessed by electrophoretic mobility shift assay. This effect was prevented by losartan $\left(10^{-7} \mathrm{M}\right), \mathrm{NAC}$ $\left(10^{-5} \mathrm{M}\right)$, and DPI $\left(10^{-6} \mathrm{M}\right)$, but not by PD123319 $\left(10^{-7} \mathrm{M}\right)$. Numbers underneath the gel represent fold expression compared with cells treated with buffer.
HGU95AV2; 12,000 genes). Changes in gene expression were assessed using Affymetrix Microarray Suite (version 4.0; Affymetrix Inc.). Microarray experiments were repeated three times with similar results. Two independent hybridizations were technically optimal, and the results shown are the mean of these two experiments. Control experiments (GeneChip Test3 Array; Affymetrix Inc.) were performed to ensure the integrity of the cRNA probes.

DNA synthesis. DNA synthesis was estimated as the amount of methyl- ${ }^{3} \mathrm{H}$-thymidine (ICN Biomedicals Inc., Irvine, California, USA) incorporated into trichloroacetic-precipitable material (36).

Migration studies. Cell migration was assessed both with a modified Boyden chamber and by an in vitro wound-healing assay. For the first approach, 13-mm filters of $8 \mu \mathrm{m}$ porosity (Whatman Inc., Clifton, New Jersey, USA) were coated with $20 \mu \mathrm{g} / \mathrm{ml}$ collagen I at $37^{\circ} \mathrm{C}$ for $30-60$ minutes. The filters were then placed between the upper and lower chambers of the Boyden system (NeuroProbe Inc., Gaithersburg, Maryland, USA). The lower chamber was filled with serum-free medium $(205 \mu \mathrm{l})$ containing the substances to be tested. Serum-starved HSCs were trypsinized and placed into the upper chamber $\left(10^{5}\right.$ cells $\left./ \mathrm{ml}\right)$. After 6 hours of incubation at $37^{\circ} \mathrm{C}$, cells adhering to the upper side of the filter were removed with a cotton swab. The filters were then fixed in $96 \%$ methanol for 2 minutes and then stained with Harris' hematoxylin solution for 1-2 minutes. Cells migrated to the lower side of the filter were counted by a light microscope at six to ten randomly chosen high-power fields. For the wound-healing assay, HSCs were cultured until con- fluence on 40-mm-diameter glass coverslips coated with $20 \mu \mathrm{g} / \mathrm{ml}$ collagen I. Cells were serum-starved for 24 hours, and a 2 -mm-wide linear wound was cleared. Cells were then incubated with agonists for 20 hours. Cells migrating into the wound were detected using a phase-contrast microscope.

Determination of TGF- $\beta 1, I L-8$, and monocyte chemoattractant protein-1 levels by ELISA. For TGF- $\beta 1$, rat HSCs were cultured in six-well plates at a density of $4.10^{5}$ cells per well for 4 days. Medium was then removed and cells challenged with agonists for 20 hours. Supernatants were collected, and an ELISA for TGF- $\beta 1$ (R\&D Systems Inc., Minneapolis, Minnesota, USA) was performed. For detection of bioactive TGF- $\beta 1$, supernatants were acidified for 20 minutes at room temperature with $1 \mathrm{~N} \mathrm{HCl}$ $(1: 50 \mathrm{vol} / \mathrm{vol})$ and then neutralized with $1 \mathrm{~N} \mathrm{NaOH}(1: 50$ $\mathrm{vol} / \mathrm{vol})$ before TGF- $\beta 1$ determination. For chemokine release, human HSCs were cultured in six-well plates at a density of $4.10^{5}$ cells per well for 24 hours. Medium was removed, and cells were incubated in serum-free medium for 24 hours in the presence of agonists. Supernatants were collected, and a sandwich ELISA for human IL-8 and monocyte chemoattractant protein-1 (MCP-1) was performed. Results are expressed as fold increase with respect to untreated cells.

Statistical analysis. Results are expressed as mean \pm SEM. For Western blot, electrophoretic mobility shift assays, and kinase assays quantitation was carried out by scanning of the intensity of the signals with NIH Image 1.63 software (NIH, Bethesda, Maryland, USA). The results were analyzed using the paired or unpaired Student's $t$ test or the Newman-Keuls test. A $P$ value of less than 0.05 was considered statistically significant. 


\section{Results}

Ang II induces ROS formation and lipid peroxidation in buman HSCs through NADPH oxidase activation. Ang II $\left(10^{-8} \mathrm{M}\right)$ induced a marked increase in ROS formation in activated human HSCs, as measured by DCFDA fluorescence (Figure 1, a and b). This effect was blocked by the AT1 receptor antagonist losartan $\left(10^{-7} \mathrm{M}\right)$, but not by the AT2 receptor antagonist PD123319 $\left(10^{-8} \mathrm{M}\right)$ (not shown). Incubation of cells with DPI $\left(10^{-6} \mathrm{M}\right)$, a specific NADPH oxidase inhibitor, markedly blunted ROS formation after Ang II exposure. To confirm that Ang II activates NADPH oxidase in human HSCs, we investigated the expression of key enzymatic components (Figure 1c). mRNAs for the cytoplasmic factor $\mathrm{p} 47^{\text {phox }}$ and the cell membrane proteins gp91 9 phox and Nox 1 were not detected in quiescent HSCs, while they were highly expressed following cell activation in culture and in cells freshly isolated from patients with liver fibrosis. In contrast, gp91 phox was only expressed in culture-activated HSCs. These data indicate that HSCs activated in vivo

Table 1

DPI prevents Ang II-induced changes in gene expression in human activated HSCs

\begin{tabular}{|c|c|c|c|c|c|c|c|}
\hline Accession no. & Gene name & Ang $\|^{A}$ & $\mathrm{DPI}+$ Ang $\|^{\mathrm{A}}$ & Accession no. & Gene name & Ang $\|^{A}$ & $\mathrm{DPI}+$ Ang $\mathrm{II}^{\mathrm{A}}$ \\
\hline \multicolumn{4}{|c|}{ Extracellular matrix } & \multicolumn{4}{|c|}{ Cell cycle/Differentiation/Apoptosis } \\
\hline M21337 & Collagen $\alpha 6(I V)$ & 13.1 & 1.0 & U49260 & Mortalin & 6.0 & 1.5 \\
\hline X05232 & Stromelysin & 7.2 & 1.1 & F062739 & FRAT2 & 4.2 & 1.3 \\
\hline M20776 & Collagen $\alpha 1(\mathrm{VI})$ & 7.0 & 2.6 & $\times 67325$ & $p 27$ & 2.0 & 0.9 \\
\hline M12272 & Collagen $\alpha 4(V I)$ & 6.8 & 2.4 & D88357 & $C D C 2$ & 4.5 & 1.1 \\
\hline U54804 & Hyaluronan synthase 2 & 7.3 & 1.4 & L42450 & p27kip1 & 4.0 & 1.1 \\
\hline AB002631 & Collectin 34 & 4.2 & 0.6 & X00088 & Histone $\mathrm{H} 2 b$ & 3.0 & 1.1 \\
\hline M12272 & PAI-2 & 3.0 & 1.2 & Aj000186 & MAD2 & 2.3 & 0.9 \\
\hline AF0908641 & $C D 44$ & 2.4 & 1.1 & AF040963 & MAD4 & 2.1 & 1.4 \\
\hline U69263 & Matrilin 2 & 2.5 & 1.0 & M14949 & $R$-ras & 2.4 & 0.9 \\
\hline U58331 & Sarcoglycan & 2.0 & 0.6 & U22376 & $c-m y b$ & 2.7 & 1.0 \\
\hline U03877 & Fibrillin-like (S1-5) & 2.1 & 0.8 & \multicolumn{4}{|c|}{ Vasoactive substances/Neurotransmitters } \\
\hline Y12779 & Enamelysin & 4.5 & 0.9 & AF004021 & PGF2 $\alpha$ receptor & 4.3 & 0.9 \\
\hline Z74615 & Collagen $\alpha 1(I)$ & 2.1 & 1.2 & D13168 & Endothelin B receptor & 7.0 & 0.7 \\
\hline U41068 & Collagen $\alpha 2(X I)$ & 3.4 & 0.7 & M88714 & Bradykinin receptor-2 & 2.1 & 1.9 \\
\hline \multicolumn{4}{|c|}{ Growth factors/Cytokines } & D14874 & Adrenomedullin & 2.0 & 0.7 \\
\hline M65062 & IGF-binding protein-5 & 8.9 & 0.8 & AF056085 & $G A B A-B$ receptor & 23.5 & 3.2 \\
\hline M59964 & Stem cell factor & 6.3 & 1.1 & X68487 & $A 2 b$ adenosine receptor & 2.0 & 0.7 \\
\hline M12272 & Angiopoietin-1 & 4.9 & 0.9 & U08989 & Glutamate transporter & 2.0 & 0.5 \\
\hline AB000734 & TIP3 & 8.1 & 2.3 & U28049 & Thromboxane B2 & 7.0 & 2.1 \\
\hline M12272 & $H G F$ & 4.6 & 2.5 & Signaling & & & \\
\hline M19154 & $T G F-\beta 2$ & 2.5 & 1.1 & L40904 & PPAR $\gamma$ & 2.0 & 1.6 \\
\hline X52599 & $\beta$ nerve growth factor & 4.4 & 2.5 & Y07867 & Pirin & 10.2 & 1.0 \\
\hline X94216 & VEGF-C & 2.6 & 1.0 & L19871 & ATF3 & 4.4 & 1.2 \\
\hline AF054598 & TGF- $\beta 1$ receptor & 2.6 & 2.3 & Y18207 & Protein phosphatase 1 & 2.5 & 1.4 \\
\hline M60828 & KGF & 2.4 & 0.9 & M90696 & Cathepsin S & 5.7 & 3.7 \\
\hline X00588 & EGF receptor & 2.1 & 1.3 & U20816 & $N F-\kappa B 2$ & 3.0 & 1.5 \\
\hline HSU66198 & FHF-2 & 5.3 & 1.2 & AJ223957 & ARNO3 & 4.0 & 9.8 \\
\hline \multicolumn{4}{|c|}{ Inflammation/Immunity } & M20560 & Lipocortin-III & 2.1 & 0.9 \\
\hline M21121 & RANTES & 6.0 & 0.9 & D50840 & Ceramide transferase & 2.4 & 1.1 \\
\hline D86322 & Calmegin & 9.2 & 2.5 & X78926 & HZF3 & 9.5 & 1.6 \\
\hline M63835 & IgG Fc receptor I & 3.2 & 0.9 & \multicolumn{4}{|c|}{ Other functions } \\
\hline U70981 & $I L-13$ & 3.4 & 0.7 & M635346 & Transferrin receptor & 2.6 & 0.9 \\
\hline AF031167 & $I L-15$ & 3.7 & 1.0 & AB009672 & ADAM 23 & 6.1 & 1.5 \\
\hline L17418 & Complement receptor-1 & 4.3 & 0.9 & M12272 & $A D H 3$ & 12.0 & 3.7 \\
\hline Y16645 & $M C P-2$ & 5.3 & 2.6 & J04027 & Calcium-pumping ATase & 2.0 & 1.1 \\
\hline M57230 & $g p 130$ & 3.7 & 0.8 & U13616 & Ankyrin 3 & 2.0 & 0.9 \\
\hline \multicolumn{4}{|c|}{ Integrins/Cytoskeleton } & U25997 & Stanniocalcin & 3.0 & 0.6 \\
\hline M12272 & Integrin $\alpha 2$ & 6.1 & 1.1 & AB002803 & BACH1 & 2.1 & 0.7 \\
\hline D88460 & $N-W A S P$ & 13.2 & 2.2 & M55153 & Transglutaminase & 5.4 & 4.5 \\
\hline M12272 & Cadherin-13 & 17.1 & 2.2 & L08850 & $A D$ amyloid & 5.7 & 13.0 \\
\hline M68892 & Integrin $\beta 7$ & 2.0 & 1.0 & M14218 & Argininosuccinate lyase & 2.4 & 0.9 \\
\hline AF032108 & Integrin $\alpha 7$ & 2.3 & 1.2 & U52112 & NCAM L1 & 4.9 & 0.9 \\
\hline
\end{tabular}

Human HSCs were stimulated with buffer or Ang II $\left(10^{-8} \mathrm{M}\right)$ for 24 hours in the presence or absence of DPI $\left(10^{-6} \mathrm{M}\right)$. Gene expression was assessed by microarray analysis (see Methods). Experiments were repeated three times. Ang II upregulated 136 genes more than twofold with respect to cells treated with buffer. DPI pretreatment prevented upregulation of most of these genes. ${ }^{A}$ The table shows fold stimulation, with respect to untreated cells, of representative genes potentially involved in liver fibrogenesis. Quantitative PCR confirmed the changes found in the microarray analysis in integrin $\alpha 2$, collagen $\alpha 1$ (VI), and angiopoietin-1 (data not shown). ADH3, alcohol dehydrogenase 3; ATF3, activating transcription factor 3; PAI-2, plasminogen activator inhibitor-2; FHF, FGF homologous factor. 


\section{Figure 3}

Ang II induces biological effects in human HSCs in a redox-sensitive manner. (a) Ang $\|\left(10^{-8} \mathrm{M}\right)$ increases DNA synthesis. This effect was prevented by losartan $\left(10^{-7} \mathrm{M}\right)$, the ERK inhibitor PD98059 $\left(5.10^{-6} \mathrm{M}\right)$, the PI3K inhibitor LY294002 (2.10-6 M), NAC $\left(10^{-5} \mathrm{M}\right)$, and DPI $\left(10^{-6} \mathrm{M}\right)$, but not by the AT2 antagonist PD123319 $\left(10^{-7} \mathrm{M}\right)$. Results are expressed as mean \pm SD of three independent experiments. ${ }^{*} P<0.01 \mathrm{vs}$. buffer; $¥ P<0.01$ vs. buffer + Ang II. (b) Ang II increased the number of HSCs migrating through a modified Boyden chamber. Pretreatment with losartan, LY294002, NAC, and DPI inhibited this effect. Results are the mean \pm SD from three independent experiments. ${ }^{*} P<0.01 \mathrm{vs}$. buffer; $\ddagger P<0.05$ vs. buffer + Ang II. (c) In vitro wound-healing assay. Ang II induced migration of cells into the wound. This effect was inhibited by losartan and DPI. Images are representative of three independent experiments. (d) Ang II induces the secretion of proinflammatory chemokines. Ang II increased secretion of IL-8 (white bars) and MCP-1 (black bars). The base-line levels of MCP- 1 and IL- 8 were $545 \pm 43 \mathrm{pg} / \mathrm{ml}$ and $119 \pm 23$ $\mathrm{Pg} / \mathrm{ml}$, respectively. Pretreatment with losartan, NAC, and DPI attenuated this effect. Incubation with PD98059, LY294002, the P38 MAPK inhibitor SB203580 (10-6 M), and the JNK inhibitor SP600125 $\left(20.10^{-6} \mathrm{M}\right)$ attenuated cytokine secretion. Results are the mean \pm SD from six independent experiments. ${ }^{*} P<0.05$ vs. buffer; ${ }^{\ddagger} P<0.05$ vs. buffer + Ang II.

express the nonphagocytic NADPH oxidase. Importantly, Ang II induced phosphorylation of $\mathrm{p} 47^{\text {phox }}$ through AT1 receptors in activated HSCs (Figure 1d). We also assessed whether ROS production by Ang II is associated with oxidative stress in HSCs. Ang II increased lipid peroxidation in HSCs, as demonstrated by induction of HNE-protein adducts (Figure 1e). Moreover, Ang II induced expression of heme oxygenase- 1 , a sensitive marker of cellular oxidative stress (40). This effect was inhibited by losartan and DPI, indicating that oxidative stress is due to AT1-induced NADPH oxidase activation. Finally, we investigated whether Ang II also induces ROS formation in hepatocytes. Ang II $\left(10^{-8} \mathrm{M}\right)$ increased intracellular ROS levels in primary rat hepatocytes and in HepG2 cells, a human hepatoblastoma cell line (not shown). In both cell types, ROS increase was slightly inhibited by DPI, suggesting that Ang II-induced ROS production in hepatocytes is mainly NADPH oxidase-independent.

Ang II activates MAPKs and AP-1 DNA-binding activity in buman HSCs in a redox-sensitive manner. We next investigated the activation of intracellular signaling molecules by Ang II. Ang II $\left(10^{-8} \mathrm{M}\right)$ markedly stimulated the MAPK components ERK-2, p38 MAPK, and JNK, as demonstrated by Western blotting of phosphorylated proteins and by kinase assays (Figure $2 a$ ). This effect was maximal between 5 and 15 minutes and was dosedependent (not shown). MAPK activation was mediat-
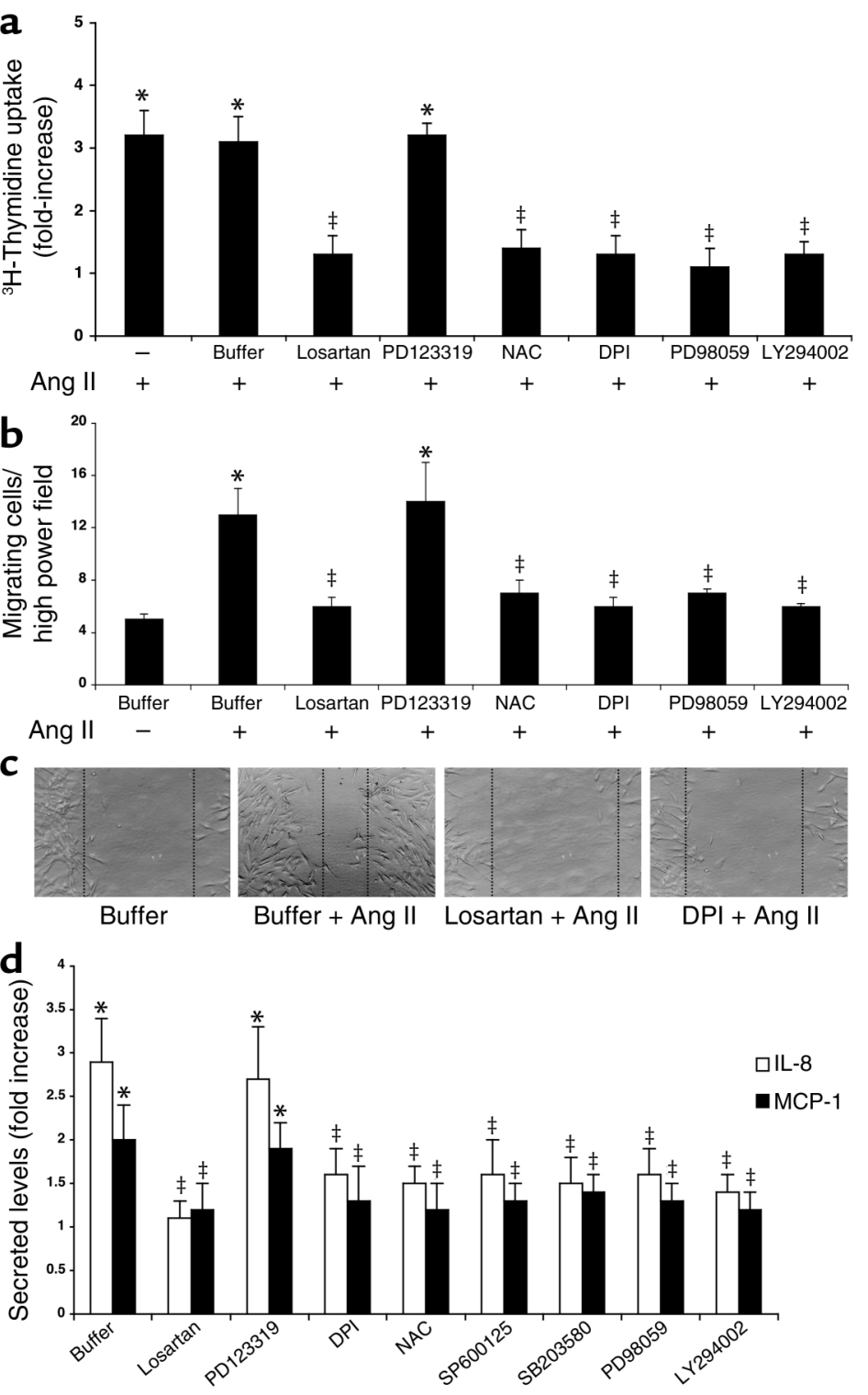

ed by AT1 and was blocked by DPI $\left(10^{-6} \mathrm{M}\right)$ and the antioxidant NAC $\left(10^{-4} \mathrm{M}\right)$. Ang II also induced phosphorylation of AKT following a similar pattern. By contrast, Ang II did not stimulate STAT1/STAT3 phosphorylation, which was markedly activated by IFN- $\gamma$ $(100 \mathrm{U} / \mathrm{l})$ (Figure 2b). Moreover, Ang II $\left(10^{-8} \mathrm{M}\right)$ increased AP-1 DNA binding in human HSCs (Figure 2c). This effect was prevented by losartan and blunted by DPI. In contrast, Ang II $\left(10^{-8} \mathrm{M}\right)$ did not activate NF- $\mathrm{KB}$ in human HSCs, as assessed by nuclear translocation of $\mathrm{p} 65$, I $\mathrm{kB}$ degradation, IKK activity, and NF- $\mathrm{\kappa B}$ reporter gene transcription assay (data not shown).

DPI prevents Ang II-induced upregulation of genes involved in wound-healing response in buman HSCs. To further elucidate the involvement of NADPH oxidase-derived ROS in Ang II-induced effects in HSCs, we performed gene-expression profiling using microarrays. Treatment of human activated HSCs with ANG $\left(10^{-8} \mathrm{M}\right)$ for 24 hours increased the expression of genes implicated 
in the wound-healing response (Table 1). These genes include ECM proteins (e.g., several collagens, matrilin and sarcoglycan), growth factors and cytokines (e.g., HGF, angiopoietin-1, and keratinocyte growth factor), proinflammatory cytokines (e.g., RANTES, IL-13, and gp130), integrins, cell cycle and/or apoptosis regulatory proteins (e.g., p27, mortalin, and MAD2), vasoactive agonists (e.g., endothelin B receptor, adrenomedullin, and thromboxane B2), and intracellular signaling factors (e.g., PPAR- $\gamma$ and cathepsin S). Importantly, preincubation of cells with DPI $\left(10^{-6} \mathrm{M}\right)$ attenuated the upregulation of most of these genes, indicating that NADPH oxidase-induced ROS mediate changes in gene expression induced by Ang II in human HSCs.

Ang II stimulates proinflammatory and fibrogenic effects in HSCs through NADPH oxidase activation. We next investigated the biological effects of Ang II on human HSCs. Cells were stimulated with $10^{-} 8 \mathrm{M}$ of Ang II, a concentration known to stimulate more than $70 \%$ of cultured HSCs (12). Ang II ( $\left.10^{-8} \mathrm{M}\right)$ increased DNA synthesis, as assessed by ${ }^{3} \mathrm{H}$-thymidine incorporation (Figure $3 \mathrm{a}$ ). This effect was prevented by losartan, by an ERK inhibitor (PD98059), and by a PI3K/AKT pathway inhibitor (LY294002), while a p38 MAPK inhibitor (SB203580) and a JNK inhibitor (SP600125) had no effect. Incubation of cells with DPI $\left(10^{-6} \mathrm{M}\right)$ or antioxidant treatment with NAC $\left(10^{-4} \mathrm{M}\right)$ inhibited Ang IIinduced DNA synthesis. Migration of HSCs was assessed with a modified Boyden chamber and an in vitro wound-healing assay. Ang II $\left(10^{-8} \mathrm{M}\right)$ induced migration of human HSCs, as demonstrated by both assays (Figure 3, b and c). This effect was blocked by ERK and PI3K/AKT inhibitors and was attenuated by DPI $\left(10^{-6} \mathrm{M}\right)$ and NAC $\left(10^{-5} \mathrm{M}\right)$. Moreover, Ang II $\left(10^{-8} \mathrm{M}\right)$ stimulated the secretion of IL-8 and MCP-1 into the culture medium (Figure $3 \mathrm{~d}$ ). Inhibition of ERK, JNK, and p38 MAPK, as well as DPI $\left(10^{-6} \mathrm{M}\right)$ and NAC $\left(10^{-4} \mathrm{M}\right)$, inhibited the increased cytokine secre-

\section{Figure 4}

Ang II exerts profibrogenic actions in rat HSCs in a redox-sensitive manner. Rat HSCs were cultured for 3 days and then stimulated for 24 hours with Ang II $\left(10^{-8} \mathrm{M}\right)$ in the presence or absence of losartan $\left(10^{-7} \mathrm{M}\right), \mathrm{NAC}\left(10^{-5} \mathrm{M}\right)$, and DPI $\left(10^{-6} \mathrm{M}\right)$. (a) Steady-state mRNA levels of procollagen $\alpha 1(\mathrm{I})$ were assessed by RNase protection assay. Data are expressed as the mean ratio between collagen $\alpha 1(\mathrm{I})$ and GAPDH mRNA levels of three independent experiments. ${ }^{*} P<0.01$ vs. buffer; $¥ P<0.05$ vs. Ang II. (b) Ang II stimulates collagen I secretion by rat HSCs. Cell supernatants were collected, proteins precipitated, and collagen I content detected by Western blotting. Relative expression is shown beneath each lane. The figure is representative of three independent experiments. (c) Ang II increases the secretion of bioactive TGF- $\beta 1$ in rat HSCs. Cells were cultured for 3 days and challenged with agonists for 20 hours. Cell medium was collected, and total and bioactive TGF- $\beta 1$ were measured by ELISA. Ang II $\left(10^{-8} \mathrm{M}\right)$ increased the secretion of bioactive TGF- $\beta 1$ by $60 \%$. Pretreatment with losartan, NAC, and DPI attenuated this effect. Results are the mean \pm SD from three independent experiments. ${ }^{*} P<0.01$ vs. buffer; $¥ P<0.05$ vs. Ang II. tion induced by Ang II. We also explored the fibrogenic effects of Ang II $\left(10^{-8} \mathrm{M}\right)$ in early-cultured HSCs (4 days in culture). For this purpose, we used male rat HSCs to circumvent the limitation on the availability of human livers. Ang II $\left(10^{-8} \mathrm{M}\right)$ increased mRNA levels of procollagen $\alpha 1$ (I) and stimulated the secretion of collagen I and bioactive TGF- $\beta 1$ in rat HSCs (Figure 4). No noticeable differences were observed in HSCs cultured from either male or female rats (data not shown). These effects were blocked by losartan and attenuated by DPI $\left(10^{-6} \mathrm{M}\right)$ and NAC $\left(10^{-4} \mathrm{M}\right)$. Finally, we explored whether NADPH oxidase regulates the spontaneous HSC activation that occurs during prolonged culture on plastic. Rat primary HSCs were cultured for 5 days and then incubated in serum-free medium in the presence or absence of DPI $\left(10^{-6} \mathrm{M}\right)$ for an additional 48 hours. DPI treatment decreased smooth muscle $\alpha$-actin expression, cell proliferation, and collagen I secretion by $40 \%, 25 \%$, and $30 \%$, respectively, compared with untreated cells (data not shown).

HSCs from p $^{\text {phbox-l- }}$ mice show attenuated response to Ang II. To further assess an involvement of NADPH oxidase in Ang II-induced actions in HSCs, we studied HSCs isolated from p47phox- - mice. Ang II $\left(10^{-8} \mathrm{M}\right)$ increased
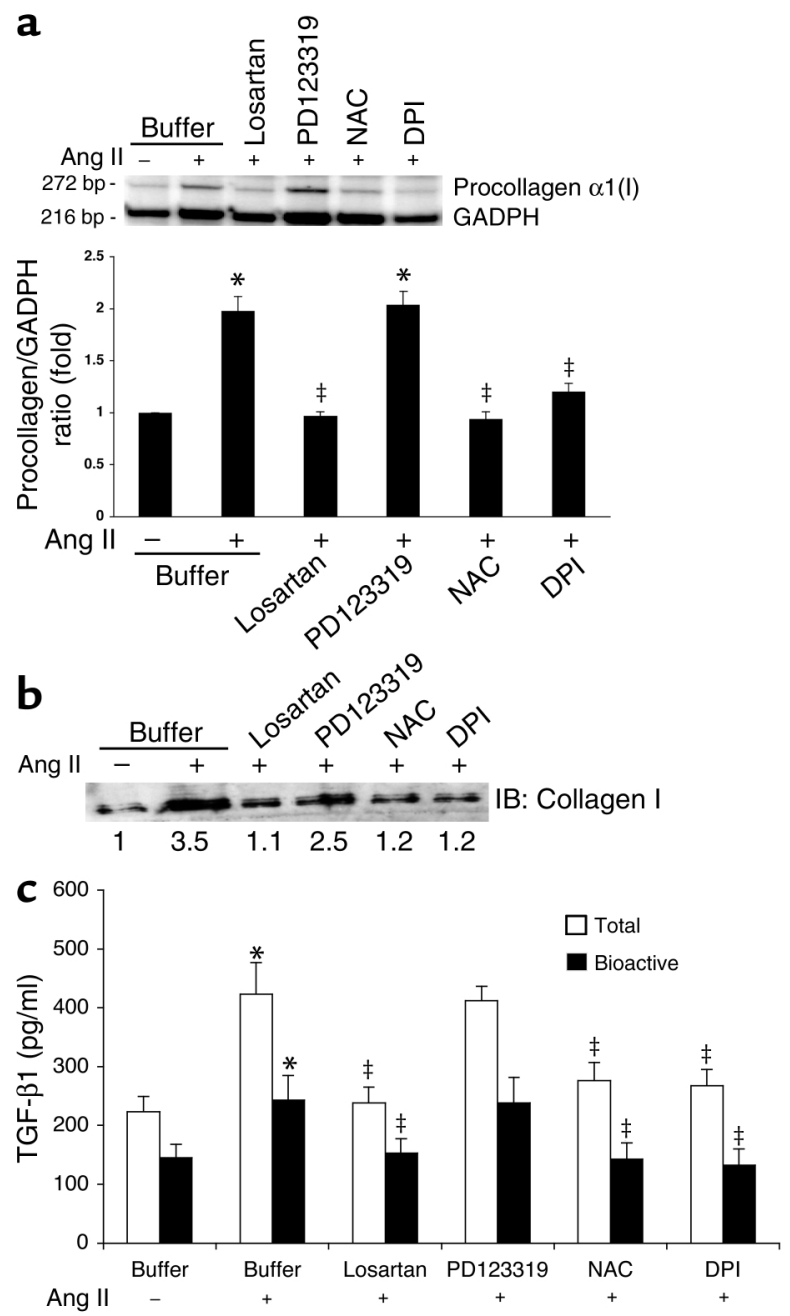


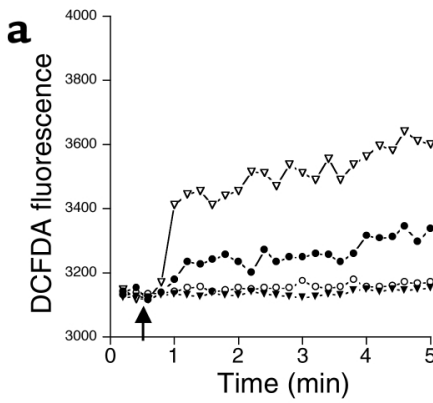

b

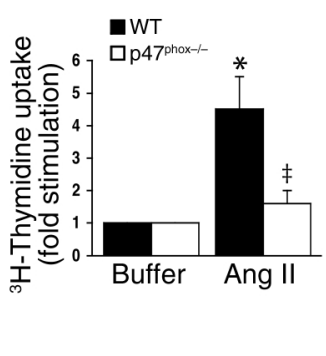

c

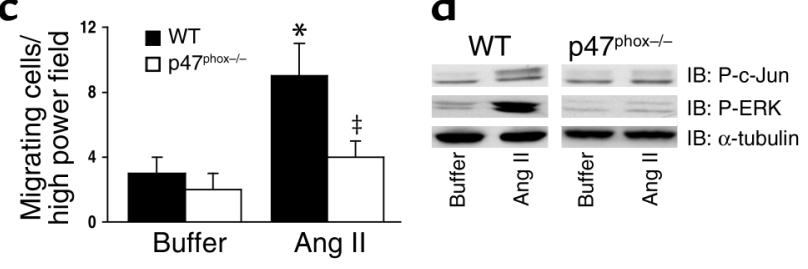

intracellular ROS in HSCs isolated from WT C57BL/6 mice, while the ROS increase was blocked in $\mathrm{p} 47 \mathrm{phox-/-}$ HSCs (Figure 5a). Ang II $\left(10^{-8} \mathrm{M}\right)$ induced DNA synthesis and cell migration in WT HSCs, as well as phosphorylation of ERK and c-Jun, while these effects were blunted in p47phox-/- HSCs (Figure 5, b-d). Collectively, these results confirm that NADPH oxidase-derived ROS play a major role in Ang II-induced actions in HSCs.

Liver fibrosis is markedly attenuated in 4 $^{47^{\text {pox }}-{ }^{-}-}$mice after bile duct ligation. To assess the role of NADPH oxidase in liver fibrosis, a model of secondary biliary fibrosis was performed in $\mathrm{p} 47^{\mathrm{phox}-/-}$ and $\mathrm{p} 47^{\mathrm{phox}^{+/+}}$mice. Following bile duct ligation for 2 weeks, the degree of liver injury was attenuated in $\mathrm{p} 47^{\mathrm{phox}-/-}$ mice, as demonstrated by lower liver/body weight ratio (Figure 6a), lower serum levels of liver enzymes (Figure 6, b-d), and lower hepatic concentration of inflammatory cytokines (Figure 6, e-h). p47phox ${ }^{++}$mice displayed severe septal fibrosis with a marked disruption of the hepatic architecture (Figure 7, a and c). Hepatic collagen content, as assessed by morphometric analysis of Sirius red staining and by hepatic hydroxyproline, was increased as expected in $\mathrm{p}^{4} 7^{\mathrm{phox}^{+/+}}$mice compared with sham-operated mice (Figure 7 , e and $\mathrm{f}$ ). In contrast, $\mathrm{p} 47 \mathrm{phox}-\mathrm{f}^{-}$mice had only mild collagen deposition without formation of bridging fibrosis (Figure 7, b and d). In addition, the increase in hepatic collagen content in bile duct-ligated 4 47phox-/- mice was markedly attenuated compared with that in $\mathrm{p}^{4} 7^{\mathrm{phox}^{+/+}}$mice (Figure 7 , e and $\mathrm{f}$ ). Moreover, staining for smooth muscle $\alpha$-actin, a marker of activated HSCs, and TGF- $\beta 1$ was diminished in livers from

\section{Figure 6}

p47phox-1- mice show attenuated liver injury after bile duct ligation. Effect of bile duct ligation for 2 weeks on liver/body weight ratio (a), serum alanine aminotransferase (ALT) (b), serum aspartate aminotransferase (AST) (c), bilirubin (d), and hepatic concentration of proinflammatory cytokines (TNF- $\alpha$, IL-1 $\beta$, MCP-1, and KC) $(\mathbf{e}-\mathbf{h}) .{ }^{*} P<0.05$ vs. sham operation; $¥ P<0.05$ vs. bile duct ligation in $p 47$ phox-/- .

\section{Figure 5}

Effects of Ang II in WT and p47phox-/- mouse HSCs. HSCs were isolated from C57BL/6WT and $\mathrm{p} 47$ phox-/- mice. Cells were studied after 14 days in culture (activated phenotype). (a) ROS production was estimated in DCFDA-loaded mouse HSCs by a fluorometer at $485 / 535 \mathrm{~nm}$. Ang II $\left(10^{-8} \mathrm{M}\right)$ increased intracellular ROS in WT HSCs (open triangles), while the increase in ROS was attenuated in p47phox-/- HSCs (filled circles). Cells exposed to buffer did not show any increase in cell fluorescence (WT, filled triangles; $47^{\text {phox- }- \text { - }}$, open circles). (b and $\mathbf{c})$ Ang II $\left(10^{-8} \mathrm{M}\right)$ increases DNA synthesis $(\mathbf{b})$ and cell migration (c) in WT mouse HSCs, as assessed by ${ }^{3} \mathrm{H}$-thymidine uptake and an in vitro migration assay in a modified Boyden chamber, respectively. These effects were markedly attenuated in $\mathrm{p} 47 \mathrm{phox}-1-$ HSCs. ${ }^{*} P<0.05$, WT buffer vs. WT Ang II. $¥ P<0.05$, WT Ang II vs. KO. (d) Effect of Ang II on phosphorylation of ERK and c-Jun, as assessed by Western blot analysis. Ang II (10-8 M) stimulates ERK and c-Jun phosphorylation in WT mouse HSCs, while both effects were markedly blunted in $\mathrm{p} 47 \mathrm{phox}-\mathrm{-}$ - HSCs. Results are representative of three independent experiments.

p47phox-/- mice compared with livers from $\mathrm{p}^{4} 7^{\mathrm{phox}^{+/+}}$ mice following bile duct ligation (Figure 7, g-k). Altogether, these results indicate than NADPH oxidase is an important mediator in experimental liver fibrosis.

\section{Discussion}

Recent evidence indicates that the renin-angiotensin system plays a role in liver fibrogenesis. The reninangiotensin system is locally expressed in injured livers, and Ang II inhibition attenuates experimental
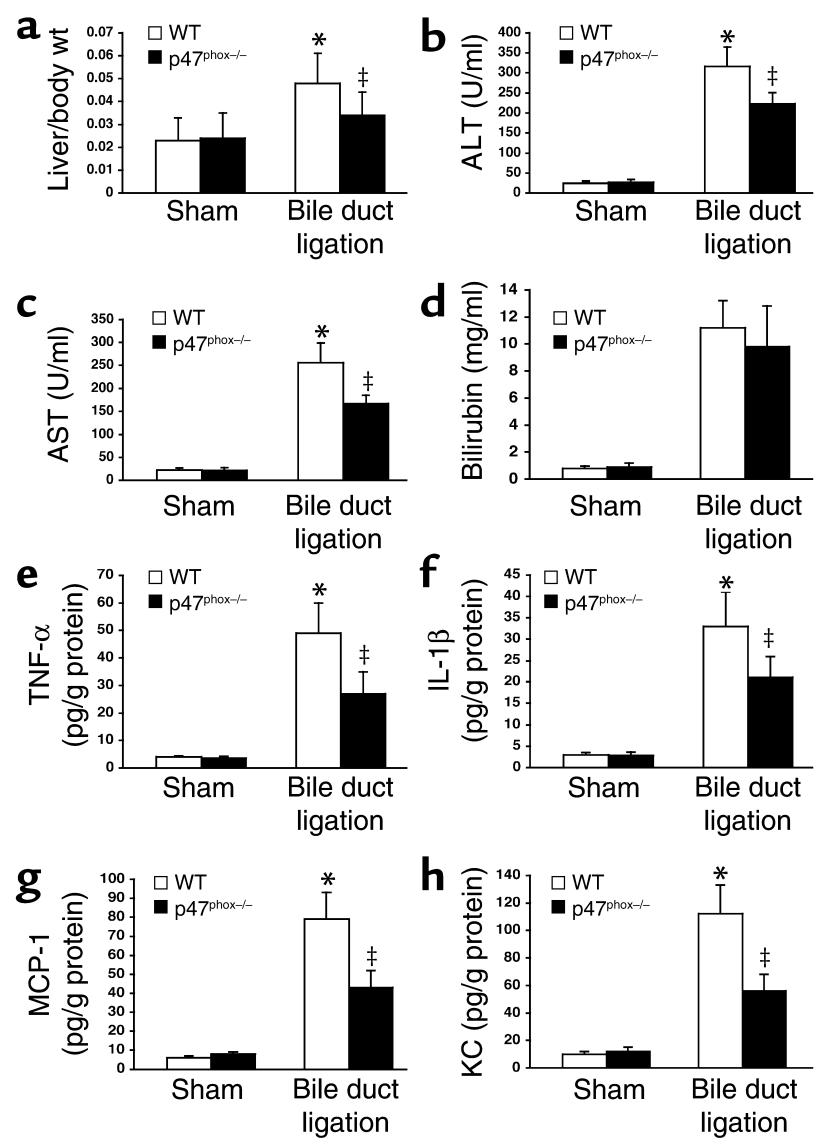
liver fibrosis (6-10). Moreover, mice lacking AT1 receptors are resistant to liver fibrosis after injury (L. Yang, unpublished observations). Although the mechanisms underlying the fibrogenic action of Ang II in the liver are unknown, ROS may play a role. Increased ROS formation and oxidative stress are common findings during liver injury, and antioxidants protect rats from developing liver fibrosis $(20,41,42)$, suggesting a role for ROS in the hepatic tissue-repair process. We recently demonstrated that increased systemic Ang II induces oxidative stress in the liver and activates HSCs (43). Therefore, we propose a link between Ang II and excess ROS production during liver fibrosis. NADPH oxidase is a major source of ROS and mediates the actions of Ang II in the vasculature $(44,45)$. We hypothesize that NADPH oxidase-derived ROS play an important role in liver fibrosis. We present evidence that Ang II induces profibrogenic actions in activated HSCs, the main fibrogenic cell in the injured liver. Moreover, NADPH oxidase-derived ROS, by activating redox-sensitive intracellular pathways, mediate Ang II-induced biological effects in these cells. Finally, disruption of an active $\mathrm{NADPH}$ oxidase protects mice from developing severe fibrosis after bile duct ligation. These findings indicate that a nonphagocytic NADPH oxidase is expressed in HSCs and plays a role in liver fibrosis.

The current study explores the mechanisms by which Ang II exerts fibrogenic effects in the injured liver. Increased systemic Ang II levels induce oxidative stress and vascular damage in the normal rat liver and exacerbate fibrosis in rats with chronic injury (43). Whether a local renin-angiotensin system also contributes to hepatic fibrogenesis is unknown. Different cell types can mediate the fibrogenic effect of Ang II in the liver. Among them, we have focused on HSCs. HSCs activate and accumulate in the injured liver, secreting inflammatory cytokines and ECM proteins and playing a key role in scar formation (46). We previously demonstrated that Ang II induces proliferation of HSCs through its binding to AT1 receptors (12). Here, we demonstrate that Ang II is a powerful chemoattractant for activated HSCs. These two functions of HSCs are believed to contribute to the accumulation of myofibroblast-like cells in the injured liver (2). Because Ang II is secreted by activated HSCs and the renin-angiotensin system is overexpressed in bile
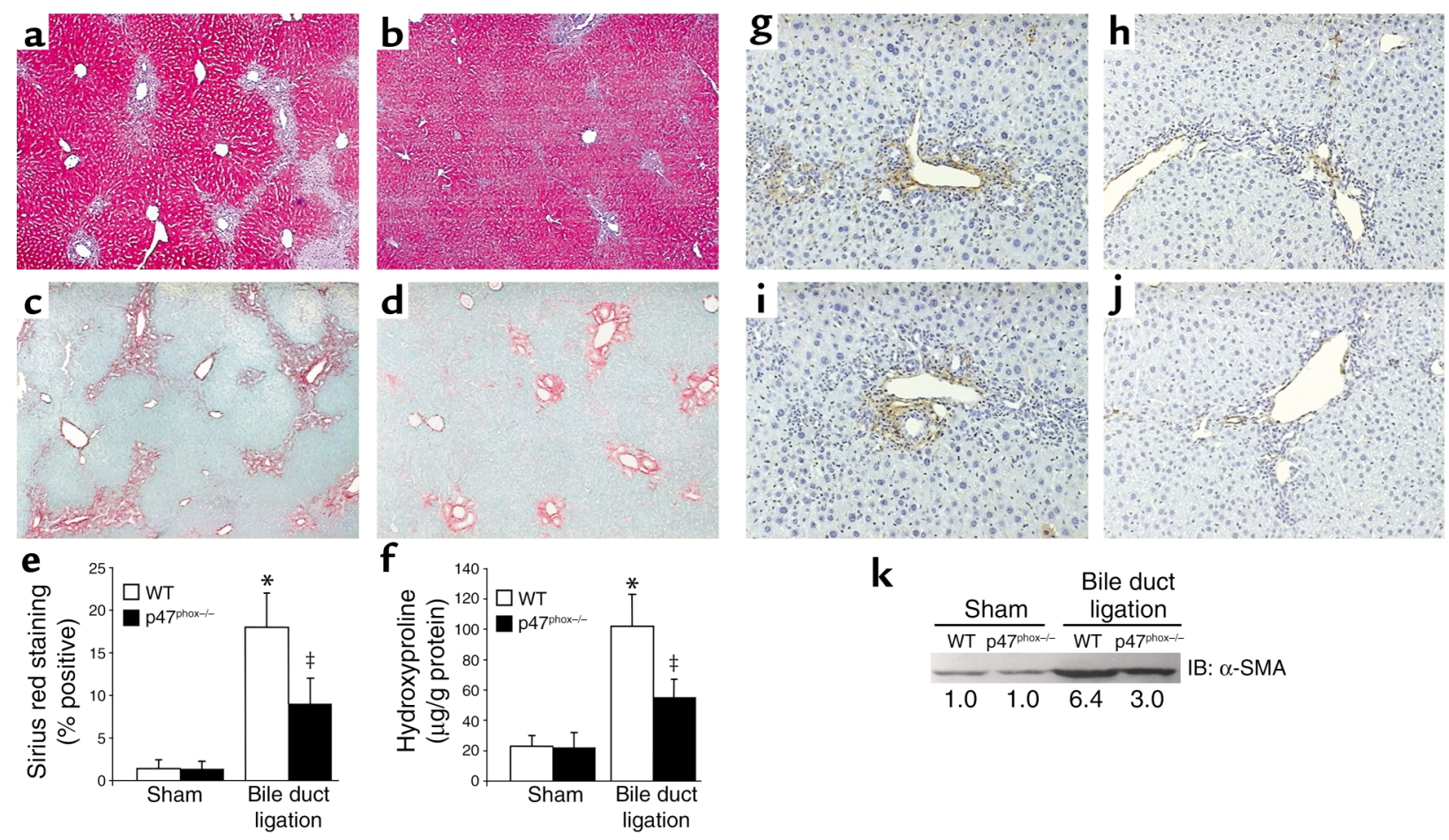

Figure 7

p47phox-/- mice are protected from liver fibrosis after bile duct ligation for 2 weeks. Representative photomicrographs of bile duct-ligated liver sections processed for Masson's trichrome ( $\mathbf{a}$ and $\mathbf{b})$ and Sirius red staining (c and $\mathbf{d})$ ). p47phoxt/+ mice developed extensive periportal damage, necrotic areas around biliary tracts, bile duct proliferation, and bridging fibrosis (a and $\mathbf{c})$. All these lesions were markedly attenuated in $\mathrm{p} 47$ phox- $/$ - mice $(\mathbf{b}$ and $\mathbf{d})$ ). (e) Quantitation of the area stained for Sirius red. ${ }^{*} P<0.05$ vs. p47phox- $/-$ mice; $\neq P<0.05$ vs. bile duct-ligated WT mice. $n=5$. (f) Hydroxyproline content in sham-operated and bile duct-ligated livers. ${ }^{*} P<0.05$ vs. sham operation; $\neq P<0.05$ vs. bile duct ligation in $\mathrm{p} 47$ phox-/-; $n=5$. Immunodetection of smooth muscle $\alpha$-actin in bile duct-ligated liver sections from $p 47$ phox $+/+(g)$ and

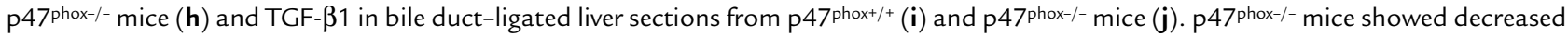
staining for both smooth muscle $\alpha$-actin and TGF- $\beta 1$ compared with $p 47$ phox $+/+$ mice. Original magnifications were $\times 40$, $\mathbf{a}-\mathbf{d}$; and $\times 100, \mathbf{g}-\mathbf{j}$. (k) Quantification of smooth muscle $\alpha$-actin ( $\alpha$-SMA) content in liver tissues by Western blotting. Relative expression is shown beneath each lane. The figure is representative of three independent experiments. 
duct-ligated livers $(4,12)$, we propose a role for Ang II in the accumulation of HSCs at the areas of tissue repair. Besides, Ang II induces the secretion of IL-8 and MCP-1 by HSCs. These two chemokines are potentially involved in the recruitment of inflammatory cells to the liver (47). In vivo, systemic infusion of Ang II into rats induces liver inflammation (43). These findings indicate that Ang II exerts proinflammatory actions in the liver. We also found that Ang II increases TGF- $\beta 1$ expression and stimulates collagen I secretion in earlycultured rat HSCs. This latter effect confirms published data showing that the blockade of Ang II inhibits TGF- $\beta 1$ expression and collagen I deposition in experimental liver fibrosis (7). Ang II also increases ROS formation and stimulates ERK in primary hepatocytes (48). It is unknown, however, whether Ang II stimulates Kupffer cells and endothelial sinusoidal cells, which play a major role in chronic liver diseases.

Intracellular ROS regulate key intracellular pathways in vascular cell types $(49,50)$. Moreover, ROS mediate the actions of Ang II in the kidney and the vasculature (51). Based on these data, we hypothesize that ROS may act as signaling molecules in HSCs mediating the response to Ang II. We demonstrate that Ang II stimulates AP-1 DNA binding, MAPKs, and AKT in HSCs. As expected, Ang II regulates the expression of genes implicated in the wound-healing process, including ECM proteins, growth factors, cytokines, cell cycle and apoptosis regulators, and vasoactive substances. Moreover, specific inhibitors of ERK and PI3K/AKT block Ang IIinduced proliferation, migration, and secretion of chemokines. Inhibition and/or genetic ablation of a functional NADPH oxidase and antioxidant treatment blunt these effects, indicating that these pathways are redox-sensitive. The functional role of NADPH oxidase-derived ROS in Ang II-induced effects in HSCs is supported by the finding that DPI strongly attenuates upregulation of genes involved in fibrogenesis. However, some of the genes potentially regulated by Ang II (e.g., IL-8) were not upregulated in the microarray experiments, suggesting that Ang II may induce post-transcriptional events in HSCs (e.g., increased IL-8 secretion). The finding that $\mathrm{p} 47$ phox is rapidly phosphorylated by ANG and is required for ROS production indicates that this subunit is required for enzymatic activity of NADPH oxidase in HSCs. Pharmacological blockade of NADPH oxidase with DPI blocks the Ang II-induced increase in ROS, confirming that NADPH oxidase mediates the increase in ROS after Ang II stimulation. In contrast, DPI only slightly decreases ROS increase in hepatocytes, indicating that Ang II-induced ROS production in hepatocytes is mainly NADPH oxidase-independent. To our knowledge, this is the first report showing that activated HSCs express functionally active NADPH oxidase. Therefore, the HSC should no longer be viewed as a passive cell reacting to ROS and cytokines secreted by neighboring cells (e.g., Kupffer cells, hepatocytes), but instead as an active participant in the liver injury that produces cytokines, chemokines, and ROS.
In the current study, we did not directly assess whether the hepatic fibrogenic effect of Ang II in vivo is mediated by NADPH oxidase. Instead, we assessed the role of NADPH oxidase in liver fibrogenesis, by subjecting mice that lack $\mathrm{p} 47^{\text {phox }}$ to a well-characterized model of secondary biliary cirrhosis. Compared with WT mice, p47phox-/- mice showed a remarkable preservation of the hepatic architecture and less fibrosis following bile duct ligation. Expression of smooth muscle $\alpha$-actin and TGF- $\beta 1$ was reduced in damaged livers from $\mathrm{p} 47 \mathrm{phox}-/-$ mice. Both findings suggest a role for NADPH oxidase in key events in liver fibrosis. Moreover, hepatic proinflammatory cytokines were lower in $\mathrm{p} 47 \mathrm{phox}-/-$ mice, suggesting that NADPH oxidase participates in the inflammatory reaction that accompanies liver fibrosis. These in vivo results indicate that NADPH oxidase plays a crucial role in the hepatic wound-healing response to injury. As we have demonstrated, nonphagocytic NADPH oxidase is activated in HSCs during liver injury. Chronic endogenous production of ROS by HSCs would activate redox-sensitive pathways that lead to inflammation and fibrogenesis. Of note, other hepatic cell types can contribute to the fibrogenic role of NADPH oxidase. In alcohol-induced liver injury, Kupffer cells express phagocytic NADPH oxidase, which generates large amounts of ROS and mediates liver injury (30). In addition, NADPH oxidase is activated in sinusoidal endothelial cells in alcohol-fed rats (52).

The results of the current study support the assumption that ROS play an important role in the pathogenesis of liver fibrosis $(13,53)$. The most accepted theory is that ROS derived from damaged hepatocytes, activated Kupffer cells, and infiltrating neutrophils stimulate HSCs in a paracrine manner $(23,54,55)$. Exogenous ROS would activate redox-sensitive intracellular pathways in HSCs to increase collagen synthesis (14, 16). Here, we present evidence that HSCs are also an important source of ROS in liver fibrosis. NADPH oxidase is expressed in culture-activated HSCs and in HSCs freshly isolated from cirrhotic livers, suggesting that in vivo-activated HSCs may generate ROS. Therefore, Ang II can generate endogenous ROS to exert its fibrogenic effect on HSCs.

\section{Acknowledgments}

This study was supported by NIH grants DK-34987 and AA-11605. R. Bataller received grants from the American Liver Foundation and the Asociación Española para Estudio del Hígado. The authors thank Blair Bradford and Michael Wheeler for providing $\mathrm{p} 47^{\mathrm{phox}-/-}$ mice, Charlotte Walters for help in ELISA assays, Jennyfer Dulyx for help in immunohistochemical studies, and Edward Lecluyse for providing human liver cells.

\footnotetext{
1. Albanis, E., and Friedman, S.L. 2001. Hepatic fibrosis. Pathogenesis and principles of therapy. Clin. Liver Dis. 5:315-334.

2. Bataller, R., and Brenner, D.A. 2001. Hepatic stellate cells as a target for the treatment of liver fibrosis. Semin. Liver Dis. 21:437-451.

3. Asbert, M., et al. 1992. Assessment of the renin-angiotensin system in cirrhotic patients. Comparison between plasma renin activity and direct measurement of immunoreactive renin. J. Hepatol. 15:179-183.
} 
4. Paizis, G., et al. 2002. Up-regulation of components of the reninangiotensin system in the bile duct-ligated rat liver. Gastroenterology. 123:1667-1676

5. Powell, E.E., et al. 2000. Host genetic factors influence disease progression in chronic hepatitis C. Hepatology. 31:828-833.

6. Ramalho, L.N., et al. 2002. Effect of losartan, an angiotensin II antagonist, on secondary biliary cirrhosis. Hepatogastroenterology. 49:1499-1502.

7. Paizis, G., et al. 2001. Effect of angiotensin II type 1 receptor blockade on experimental hepatic fibrogenesis. J. Hepatol. 35:376-385.

8. Yoshiji, H., et al. 2002. Inhibition of renin-angiotensin system attenuates liver enzyme-altered preneoplastic lesions and fibrosis development in rats. J. Hepatol. 37:22-30.

9. Wei, H.S., et al. 2000. The regulatory role of AT 1 receptor on activated HSCs in hepatic fibrogenesis: effects of RAS inhibitors on hepatic fibrosis induced by $\mathrm{CCl}(4)$. World J. Gastroenterol. 6:824-828.

10. Croquet, V., et al. 2002. Hemodynamic and antifibrotic effects of losartan in rats with liver fibrosis and/or portal hypertension. J. Hepatol. 37:773-780

11. Mezzano, S.A., Ruiz-Ortega, M., and Egido, J. 2001. Angiotensin II and renal fibrosis. Hypertension. 38:635-638.

12. Bataller, R., et al. 2000. Angiotensin II induces contraction and proliferation of human hepatic stellate cells. Gastroenterology. 118:1149-1156.

13. Parola, M., and Robino, G. 2001. Oxidative stress-related molecules and liver fibrosis. J. Hepatol. 35:297-306.

14. Svegliati Baroni, G., et al. 1998. Fibrogenic effect of oxidative stress on rat hepatic stellate cells. Hepatology. 27:720-726.

15. Liu, T.Z., et al. 2001. Free radical-triggered hepatic injury of experimental obstructive jaundice of rats involves overproduction of proinflammatory cytokines and enhanced activation of nuclear factor kappaB. Ann. Clin. Lab. Sci. 31:383-390.

16. Greenwel, P., Dominguez-Rosales, J.A., Mavi, G., Rivas-Estilla, A.M., and Rojkind, M. 2000. Hydrogen peroxide: a link between acetaldehydeelicited alpha1(I) collagen gene up-regulation and oxidative stress in mouse hepatic stellate cells. Hepatology. 31:109-116.

17. Kim, K.Y., Choi, I., and Kim, S.S. 2000. Progression of hepatic stellate cell activation is associated with the level of oxidative stress rather than cytokines during CCl4-induced fibrogenesis. Mol. Cells. 10:289-300.

18. Ohhira, M., et al. 1998. Immunohistochemical detection of 4-hydroxy2-nonenal-modified-protein adducts in human alcoholic liver diseases. Alcohol. Clin. Exp. Res. 22(Suppl.):145S-149S.

19. Mato, J.M., et al. 1999. S-adenosylmethionine in alcoholic liver cirrhosis: a randomized, placebo-controlled, double-blind, multicenter clinical trial. J. Hepatol. 30:1081-1089.

20. Zhong, Z., et al. 2002. Viral gene delivery of superoxide dismutase attenuates experimental cholestasis-induced liver fibrosis in the rat. Gene Ther 9:183-191.

21. Tsukamoto, H., Rippe, R., Niemela, O., and Lin, M. 1995. Roles of oxidative stress in activation of Kupffer and Ito cells in liver fibrogenesis. J. Gastroenterol. Hepatol. 10(Suppl. 1):S50-S53.

22. Svegliati-Baroni, G., et al. 2001. Involvement of reactive oxygen species and nitric oxide radicals in activation and proliferation of rat hepatic stellate cells. Liver. 21:1-12

23. Nieto, N., Friedman, S.L., and Cederbaum, A.I. 2002. Stimulation and proliferation of primary rat hepatic stellate cells by cytochrome P450 2E1-derived reactive oxygen species. Hepatology. 35:62-73.

24. Babior, B.M., Lambeth, J.D., and Nauseef, W. 2002. The neutrophil NADPH oxidase. Arch. Biochem. Biophys. 397:342-344.

25. Weintraub, N.L. 2002. Nox response to injury. Arterioscler. Thromb. Vasc. Biol. 22:4-5.

26. Viedt, C., et al. 2000. Differential activation of mitogen-activated protein kinases in smooth muscle cells by angiotensin II: involvement of p22phox and reactive oxygen species. Arterioscler. Thromb. Vasc. Biol. 20:940-948.

27. Wang, H.D., Johns, D.G., Xu, S., and Cohen, R.A. 2002. Role of superoxide anion in regulating pressor and vascular hypertrophic response to angiotensin II. Am. J. Physiol. Heart Circ. Physiol. 282:H1697-H1702.

28. Vignais, P.V. 2002. The superoxide-generating NADPH oxidase: structural aspects and activation mechanism. Cell. Mol. Life Sci. 59:1428-1459.

29. Cheng, G., Cao, Z., Xu, X., van Meir, E.G., and Lambeth, J.D. 2001. Homologs of gp91phox: cloning and tissue expression of Nox3, Nox4, and Nox5. Gene. 269:131-140.
30. Kono, H., et al. 2000. NADPH oxidase-derived free radicals are key oxidants in alcohol-induced liver disease. J. Clin. Invest. 106:867-872.

31. Kono, H., et al. 2001. Diphenyleneiodonium sulfate, an NADPH oxidase inhibitor, prevents early alcohol-induced liver injury in the rat. Am. J. Physiol. Gastrointest. Liver Physiol. 280:G1005-G1012.

32. Wheeler, M.D., et al. 2001. The role of Kupffer cell oxidant production in early ethanol-induced liver disease. Free Radic. Biol. Med. 31:1544-1549.

33. Jackson, S.H., Gallin, J.I., and Holland, S.M. 1995. The p47phox mouse knock-out model of chronic granulomatous disease. J. Exp. Med. 182:751-758

34. Bataller, R., et al. 1997. Arginine vasopressin induces contraction and stimulates growth of cultured human hepatic stellate cells. Gastroenterology. 113:615-624.

35. Schnabl, B., et al. 2001. TAK1/JNK and p38 have opposite effects on rat hepatic stellate cells. Hepatology. 34:953-963.

36. Schnabl, B., et al. 2001. The role of Smad3 in mediating mouse hepatic stellate cell activation. Hepatology. 34:89-100.

37. Schwabe, R.F., and Brenner, D.A. 2002. Role of glycogen synthase kinase3 in TNF-alpha-induced NF-kappaB activation and apoptosis in hepatocytes. Am. J. Physiol. Gastrointest. Liver Physiol. 283:G204-G211.

38. Schwabe, R.F., Schnabl, B., Kweon, Y.O., and Brenner, D.A. 2001. CD40 activates NF-kappa B and c-Jun N-terminal kinase and enhances chemokine secretion on activated human hepatic stellate cells. J. Immunol. 166:6812-6819.

39. Schwabe, R.F., Bennett, B.L., Manning, A.M., and Brenner, D.A. 2001. Differential role of I kappa B kinase 1 and 2 in primary rat hepatocytes. Hepatology. 33:81-90.

40. Bauer, M., and Bauer, I. 2002. Heme oxygenase-1: redox regulation and role in the hepatic response to oxidative stress. Antioxid. Redox Signal. 4:749-758.

41. Yamamoto, Y., Yamashita, S., Fujisawa, A., Kokura, S., and Yoshikawa, T. 1998. Oxidative stress in patients with hepatitis, cirrhosis, and hepatoma evaluated by plasma antioxidants. Biochem. Biophys. Res. Commun. 247:166-170

42. Kim, K.Y., Rhim, T., Choi, I., and Kim, S.S. 2001. N-acetylcysteine induces cell cycle arrest in hepatic stellate cells through its reducing activity. J. Biol. Chem. 276:40591-40598.

43. Bataller, R., et al. 2003. Systemic infusion of angiotensin II into normal rats induces stellate cell activation and pro-inflammatory events in the liver. Am. J. Physiol. 285:G642-G651.

44. Strawn, W.B., and Ferrario, C.M. 2002. Mechanisms linking angiotensin II and atherogenesis. Curr. Opin. Lipidol. 13:505-512.

45. Landmesser, U., et al. 2002. Role of p47(phox) in vascular oxidative stress and hypertension caused by angiotensin II. Hypertension. 40:511-515.

46. Friedman, S.L. 2003. Liver fibrosis: from bench to bedside. J. Hepatol. 38(Suppl. 1):S38-S53.

47. Marra, F., et al. 1998. Increased expression of monocyte chemotactic protein-1 during active hepatic fibrogenesis: correlation with monocyte infiltration. Am. J. Pathol. 152:423-430.

48. Weng, Y.I., and Shukla, S.D. 2003. Effects of chronic ethanol treatment on the angiotensin II-mediated $\mathrm{p} 42 / \mathrm{p} 44$ mitogen-activated protein kinase and phosphorylase a activation in rat hepatocytes. Alcohol. 29:83-90.

49. Brandes, R.P., et al. 2002. The vascular NADPH oxidase subunit p47phox is involved in redox-mediated gene expression. Free Radic. Biol. Med. 32:1116-1122.

50. Berk, B.C. 1999. Redox signals that regulate the vascular response to injury. Thromb. Haemost. 82:810-817.

51. Griendling, K.K., and Ushio-Fukai, M. 2000. Reactive oxygen species as mediators of angiotensin II signaling. Regul. Pept. 91:21-27.

52. Whalen, R., Rockey, D.C., Friedman, S.L., and Boyer, T.D. 1999. Activation of rat hepatic stellate cells leads to loss of glutathione S-transferases and their enzymatic activity against products of oxidative stress. Hepatology. 30:927-933.

53. Lieber, C.S. 2000. Alcoholic liver disease: new insights in pathogenesis lead to new treatments. J. Hepatol. 32:113-128.

54. Casini, A., et al. 1997. Neutrophil-derived superoxide anion induces lipid peroxidation and stimulates collagen synthesis in human hepatic stellate cells: role of nitric oxide. Hepatology. 25:361-367.

55. Hoek, J.B., and Pastorino, J.G. 2002. Ethanol, oxidative stress, and cytokine-induced liver cell injury. Alcohol. 27:63-68. 